\title{
A Comparison of the Current Account and the Monetary Theories of Exchange Rate Determination
}

\author{
Augustine C. Arize ${ }^{1}$, Ioannis N. Kallianiotis ${ }^{2}$, John Malindretos ${ }^{3}$, Alex Panayides ${ }^{3} \&$ Demetri Tsanacas $^{4}$ \\ ${ }^{1}$ Department of Economics and Finance, College of Business, Texas A\&M University, USA \\ ${ }^{2}$ Department of Economics and Finance, Arthur Kania School of Management, University of Scranton, USA \\ 3 Department of Economics, Finance and Global Business, Cotsakos College of Business, William Paterson \\ University, Wayne, New Jersey, USA \\ ${ }^{4}$ Department of Business Administration, School of Social Sciences and Professional Studies, USA \\ Correspondence: John Malindretos, Department of Economics, Finance and Global Business, Cotsakos College \\ of Business, William Paterson University, Wayne, New Jersey, USA. E-mail: MALINDRETOSJ@wpunj.edu
}

Received: May 9, 2017

doi:10.5539/ijef.v10n2p102
Accepted: December 30, 2017

Online Published: January 10, 2018

\begin{abstract}
In this study, we develop a way to test for the two theories, the Monetary and the current account, in explaining exchange rate determination. The approach we develop has two components to it. The first is a test of the appropriate signs. That is, the two theories disagree on the signs of the determining variables. Thus, depending on the sign of the regressors, we can prove the one, or the other. The second sub test is one which has to do with the speed of adjustment. Specifically, importance should be depicted in a quicker speed of adjustment. On that issue, if real(monetary) variables adjust faster, then it supports the traditional (monetary) view.
\end{abstract}

Keywords: exchange rate determination, current account view, monetary approach, speed of adjustment, econometric testing, Keynesian view

\section{Introduction}

There has been an extensive amount of literature on the determination of exchange rates. Three good surveys are by Peter Isard in 1978, Hedrick in 1987, and by Magee in 1976.

The traditional theory of exchange rate determination is a theory that has existed since the beginning of this century. Many famous financiers have worked to establish the traditional approach to the determination of exchange rates. Some of them are Sidney (1852), John (1823), Fritz, James (1851) and Joan (1947). Since the traditional point of view relates to a keynesian mode, the name that we may use to describe it is "the Keynesian Approach". As we have analyzed however elsewhere, the term keynesian does not do justice to the view which we shall call traditional. (Malindretos, 1984). The TA approach includes the Portfolio Balance approach (Branson, 1968) the international Fisher effect (Cumby \& Obstfeld, 1981), the balance of payments view (Einzig, 1970), the forward exchange theory (Keynes, 1923) and the speculative view (Grubel, 1965).

\section{The Traditional Approach to ER Determination}

We can divide the TA to ER determination into two subtheories. The reason is that there exist two different international accounts in the balance of payments and both influence the ER. Those two accounts are the trade balance of goods and services and the other is the capital account.

The fundamental variable which affects the ER in the TA is the trade balance of goods and services. But, since part of the services account is composed of investment flows, it is best to refer to the trade balance (TB) only. The TB influences the ER due to the supply of, let us say, dollars versus the demand for dollars. The supply of dollars . is engendered by a rise in imports and the demand for dollars by a rise in exports. The variables which determine the TB of a nation are the income level, the money supply and the price level of the domestic products versus the foreign products.

The purchasing power of a nation relatively to the other determines its TB. Purchasing power of the nation is determined by its income and its monetary policy. The higher the income of a nation is the greater its purchases of imports are and the greater the deficit of the TB is or the lower the TB surplus is. Economic expansion thus 
worsens the TB of the nation. This induces the ER to devalue. The same result is achieved if the money supply of the focus nation expands. Residents of the focus nation will have a higher income, and so they will buy more imports and thus worsen the TB of their nation and cause the ER to depreciate.

Secondly, the price level of the nation relatively to the rest of the world affects the competitiveness of the nation. If the nation has a rise in its price level, then it becomes less competitive than the rest of the world (ROW), and so it exports less while it imports more. This will worsen the TB and consequently make the focus currency depreciate. If, on the other hand, the price level falls or rises less than the rest of the world, the focus nation will become more competitive, and it will improve its TB and its currency will appreciate.

The TA states that an important determinant of the ER is the capital account or the account of flows of international securities. A fundamental variable of security flows is the rate of interest. Rising rates of interest domestically will tend to attract more funds to the focus nation.and induce the domestic currency to appreciate. Falling interest rates will induce an a depreciation of the currency.

\section{The Monetary Approach to ER Determination}

The Monetary Approach (MA) has concentrated on the official reserves transactions balance (ORTB) almost exclusively. The MA revolves around the supply of and the demand for money. An excess supply of money domestically will induce an outflow of it to the ROW and have the BOP worsen and the currency depreciate. An excess demand of money, on the other hand, will cause the currency to appreciate since it causes an inflow of funds domestically.

A monetary expansion (tightening) of the focus nation will ceteris paribus make the currency depreciate (appreciate), since it will create an excess supply of (demand for) money. A rise (fall) in the interest rates domestically will cause the ER to depreciate (appreciate) because the demand for money will fall (rise). This is in exact opposition to the traditional conclusions and the mechanism is different in the context of adjustment.

If the income level of the focus country rises (falls) the ER will appreciate (depreciate). The reason for this happening is that in case that the income level rises (falls) the ctemand for money rises (falls), and this causes the currency to appreciate (depreciate). As far as the price level is concerned, the mechanism of adjustment according to the MA works in the same fashion that the income level does. If the price rises (falls), the demand for money rises (falls) and the currency appreciates (depreciates). This is in direct contrast to the conclusions of the TA.

Finally, the ORTB influences the ER as follows. If the ORTB improves (worsens), the currency appreciates (depreciates). This occurs because if the ORTB improves (worsens) there is an influx (efflux) of funds.

\section{Review of the Literature on Comparison of the Two Theories of International Finance on Exchange Rate Determination.}

\subsection{The Traditional Theory of ER Determination}

The TA to ER determination has been tested thoroughly, (Isard, 1976). A few notable studies of the different divisions of the TA are: Cumby and Obstfeld (1981) of the international Fisher effect, Grubel (1965) of the speculation view.

\subsection{The MA to ER Determination}

The Monetary approach to exchange rate determination is a relatively new theory developed since the early sixties. The financiers who are associated with the monetary approach are people like Rudiger Dornbusch, Jacob Frenkel, and Harry Johnson (1976), Arthur Laffer (1982), and most importantly Robert Mundell (1968). However, some argue that the monetary approach existed even before the traditional approach did in the seventeenth and eighteenth centuries. A few of the studies of the MA to ER determination are by Frenkel (1976), Bilson (1978), Hedrick (1978), Humphrey and Lawler (1978) and Girton and Roper (1977).

\subsection{A Comparison of the Traditional and the Monetary Theories of ER Determination}

The two views of international finance seemingly describe the same issues. But there are big differences between them. These differences are the reason that the two views disagree so much on their conclusions and on policy recommendations. The two views have a discord on their assumptions, their emphasis on real versus monetary variables, and their emphasis on international accounts (Malindretos, 1991).

\section{A. The Discord on the Assumptions of the Two Views of International Finance.}

The MA has four assumptions which are the bedrock upon which the rest of the theory is based. Those are, in an increasing order of importance, the following: (Malindretos, 1988). 
1) There exists full employment of inputs.

2) Purchasing power parity holds true.

3) Money markets are the essential markets to consider.

4) General equilibrium of all markets exists.

The MA survives unscathed even in the absence of the first two assumptions. The fundamental assumption of the MA are the last two. Those two assumptions are necessary and sufficient.

B. The Discord on the Emphasis of Real Versus Monetary variables by the Two Views of International Finance The TA has the same philosophical view as the Keynesian theory of income domestically. That is, the TA like its predecessor, the Keynesian theory of income, emphasizes real economic variables. The real economic variables that the TA analyzes as important determinants of the ER are the income, relative price, and governmental spending variables. The TA believes that the above variables are the key ones to use in order to explain the determination of the currency's value. In fact, any monetary variables such as the price level or the money supply must go through real variables to influence the ER. The price level, for example, must affect the international accounts by inducing a real change, ie, an enhancement of competitiveness where the focus nation's products become cheaper in comparison to the foreign nation's products. The money supply induces a change in the international accounts, finally, by its influence on the income of the nation and consequently on the importation of the nation and on the ER finally.

Thus, in the TA the transmission mechanism occurs mainly through real variables. Monetary variables are definitely of secondary importance. If monetary variables alter, they will influence the ER only after they affect real variables which, in turn, will affect the international accounts which, in turn, will influence the ER. The influence of monetary variables upon the ER is indirect while the influence of real variables on the ER direct. If real variables influence the ER directly and monetary variables influence it indirectly, then real variables are the important variables and monetary variables are the less important variables in ER determination a la TA. (Malindretos, 1984).

The MA, on the other hand, claims superiority for monetary variables as monetarism claims for the domestic determination of income. Monetary variables such as the price level, the money supply and the interest rate are the fundamental variables in influencing the ER. In the MA the price level does not have to affect the competitiveness of the nation which is a real concept but can influence the ER by first influencing the demand for money, and then influencing the international accounts and the ER. The same transmission mechanism holds true in the case of the interest rate. The money supply, lastly, affects the balance of payments directly. All monetary variables affect the ER directly without having to travel through real variables.

Real variables, however, have to indirectly influence the ER. If income, for example, altered, it would not affect the ER by affecting the international accounts first and then the ER, but it would need to first influence the money market according to the monetary approach. After it would alter the demand for money, it would influence the ER.

The same approach applies to governmental spending. If it were to alter, the influence would have to travel through the money market and then affect the ER. Therefore, in the MA real variables have a clearly secondary position to monetary ones.

C. The Discord on Accommodating Versus Initiating International Accounts and the Two Views of International Finance (Kemp, 1975).

The third important difference between the TA and the MA is the emphasis on different international accounts. The TA puts its weight on the merchandise trade balance. It feels that the TB is the autonomous account. It views the official reserves transactions balance as simply an accommodating account. The implication is that the TB would have a closer relationship to the ER according to the TA. The coefficient of determination between the TB and the ER would exceed that of the ORTB and the ER.

The MA says the exact opposite. The most important account according to it is the ORTB, and it would be the account which is autonomous. The TB would adjust to the whims of the ORTB. If this is true, then the more important determinant among the two accounts is the ORTB. According to the monetary approach, the ORTB would have the closer correlation with the ER than the TB would have.

The former analysis brings out the point that the TA emphasizes the TB which is the real account and the MA emphasizes the ORTB which is the monetary account. Again we see that the essential variables for the TA are real variables and the essential variables for the MA are the monetary variables. 


\section{The Model}

We have a model for the ER according to the TA and another model according to the MA. The basic model that we used is the. Almon polynomial distributed model. (Almon, 1965) The reasons for our choice were (Dutta, 1975):

1). The polynomial distributed model is not very restrictive. The pattern is loose enough so that is can depict the true relationship between the regressors and the regressand.

2). We can separate the adjustment lags for the diverse regressors.

3 ). We can use ordinary least squares in combination with the Almon polynomial distributed lag model (Pindyck \& Rubinfeld, 1981).

Another interesting approach we could have used is the one by Lee et al. (1987). We hope to soon use this view in further econometric work that we are undertaking.

\subsection{The Model According to the Traditional View}

The model for the TA is (Isard, 1978)

$$
E R_{t}=a_{t}+\sum_{j=1}^{n} b_{j} P R_{t-j}+\sum_{j=1}^{n} c_{j} P_{t-j}+\sum_{j=1}^{n} d_{j} M_{t-j}+\sum_{j=1}^{n} e_{j} I_{t-j}+\sum_{j=1}^{n} f_{j} T B_{t-j}+\sum_{j=1}^{n} g \text { ORTB } B_{t-j}+U_{t}
$$

where $E R_{t}=$ the exchange rate at time period defined as the euro given per u.s. dollar.

$\mathrm{PR}=$ industrial production of the US minus industrial production of the world.

$\mathrm{p}=$ price of exports minus price of imports in an index form

$\mathrm{M}=$ money supply of US minus money supply of the world in absolute units. (non index form)

$\mathrm{I}=$ domestic interest rate minus world interest rate.

$\mathrm{TB}=$ Trade Balance of goods and services of US

ORTB $=$ The official reserves transaction balance of US. $a j=$ constant

$b_{j}=$ the industrial production coefficients

$c_{j}=$ the price of exports minus the price of imports coefficients.

$d_{j}=$ the money supply coefficients

$e_{j}=$ the interest rate coefficients

$f_{j}=$ the trade balance coefficient

$g_{j}=$ the official reserves transactions balance coefficients $u t=$ an error term.

\subsection{The Model According to the Monetary View}

The monetary model of ER determination would be similar to that of the TA model: (Magee, 1976)

$$
E R=a_{t}^{\prime}+\sum_{j=1}^{n} b_{j}^{\prime} P R_{t-j}+\sum_{j=1}^{n} c_{j}^{\prime} p_{t-j}^{\prime}+\sum_{j=1}^{n} d_{j}^{\prime} M_{t-j}^{\prime}+\sum_{j=1}^{n} e_{j}^{\prime} I_{t-j}^{\prime}+\sum_{j=1}^{n} f_{j}^{\prime} T B_{t-j}+\sum_{j=1}^{n} g_{j}^{\prime} \text { ORTB } B_{t-j}+U_{t}^{\prime}
$$

\subsection{The Model: Introduction to Empirical Comparison}

The tests that we shall use are of two kinds. The first test is that of signs and the second test is that of speed of adjustment.

1) The Test of Signs

The first test that we shall use is a comparison of the signs of the regressors in the two equations. To review what we have already expressed, the Current account predicts that the sign of the production, price and money supply coefficients will be negative. On the other hand, the sign of the interest rate, trade balance and official transactions balance will be positive.

The Monetary approach contradicts the Current account approach. It states that the signs of the production, price and money supply coefficients will be positive. But the sign of the interest rate coefficient will be negative.

2) The Test of Speed of Adjustment

This test is more definitive than the first one. A similar approach is used by Malindretos (1991). The quickness of 
adjustment of the ER should differ depending on which variable is altering. More specifically the TA would argue that since real variables are more important than monetary variables they should affect the ER faster than monetary variables would in case that both independent variables alter. In contrast to that, the MA would argue that monetary variables would jolt the ER before real variables would do so, since monetary variables are the key culprits of any disturbance.

Real variables are the industrial production, and the trade balance of goods and services. Monetary variables are the interest rate,the price level, the money supply and the official reserves transactions balance.

\section{Conclusion}

This study gives evidence that we can compare the two approaches of exchange rates, the current account versus the monetary approach. Specifically, they argue that we can design an empirical model to test the two views. The two tests are first the test of signs and second, the test of speed of adjustment.

\section{References}

Agacer, G. M., Arize, C. A., Kasibhatla, M. K., Kallianiotis, N. I., \& Malindretos, J. (2015). Several Econometric Tests of Exchange Rate Efficiency for a Few European Countries. International Journal of Financial Research, 6(4), 194-206. http://dx.doi.org/10.5430/ijfr.v6n4p194

Alexander, S.(1952). Effects of a Devaluation on a Trade Balance. International Monetary Fund staff Papers, 2(April), 263-78. https://doi.org/10.2307/3866218

Arize, A., Ioannis, N. K., Liu, S., Malindretos, J., \& Verrios, A. (2015). Statistical Specifications and Diverse Tests of Efficiency in European Foreign Exchange Markets. International Journal of Economics and Finance, 7(10), 235-246. https://doi.org/10.5539/ijef.v7n10p235

Arize, A., Malindretos. J., \& Ghosh, D. (2015). Purchasing Power Parity-Symmetry and Proportionality: Evidence in 116 Countries. International Review of Economics and Finance, 37, 69-85. https://doi.org/10.1016/j.iref.2014.11.014

Arize, C. A., Berendt, C., Kallianiotis, N. I, Malindretos, J., \& Panayides, A. (2015). Prognostication Models Applied to the US Dollar and the Japanese Yen. The International Journal of Finance, 27(4).

Arize, C. A., Berendt, C., Campanelli-Andreopoulos G., Kallianiotis, N. J., \& Malindretos, J. (2016). Foreign Currency Forecasts: A Combination Analysis. NMIMS Journal of Economics and Public Policy, 1(2), 16-22.

Arize, C. A., Berendt, C., Campanelli- Andreopoulos, G., Kallianiotis, I. N., \& Malindretos, J. (2017). Foreign Currency Prognostication: Diverse Tests for Germany. International Journal of Financial Research, 8(3).

Arize, C. A., Kallianiotis I, N. K., Kalu, E. E., Malindretos, J., \& Scoullis, M. (2017). A Multitude of Econometric Tests Forecasting the Dutch Guilder. International Journal of Economics and Finance, 9(9), 94-102. https://doi.org/10.5539/ijef.v9n9p94

Arize, C. A., Malindretos., \& Emmanuel, I. (2017). Do Exchange Rate Changes Improve the Trade Balance? An Assymmetric Non linear Cointegration Approach. International Review of Economics and Finance, (49), 313-326.

Branson, W. (1968). Financial capital Flows in the u.s. Balance of Payments. Amsterdam: North Holland Publishing Co.

Cumby, R. F., \& Obstfeld, M. (1981). A Note on Exchange Rate Expectations and Nominal Interest Differentials: A Test of the Fisher Hypothesis. Journal of Finance, (6), 687-703. https://doi.org/10.1111/j.1540-6261.1981.tb00654.x

Frenkel, J. A. (1976). A Monetary Approach to the Exchange Rate: Doctrinal Aspects and Empirical Evidence. Scandinavian Journal of Economics, 78(2), 200-24. https://doi.org/10.2307/3439924

Frenkel, J. A., \& Johnson, H. G. (1976). The Monetary Approach to the Balance of Payments. Toronto: University of Toronto Press.

Frenkel, J. A., \& Johnson, H. G. (Eds.) (1978). The Economics of Exchange Rates. Reading MA: Addison-Wesley.

Frenkel, J. A., Gylfason, T., \& Helliwell, J. F. (1980). A Synthesis of Monetary and Keynesian Approaches to Short-Run Balance of Payments Theory. The Economic Journal, 90(September), 582-92. https://doi.org/10.2307/2231928

Grubel, H. G. (1965). Profits From Forward Exchange Speculation. Quarterly Journal of Economics, 79, 248-62. 
https://doi.org/10.2307/1880630

International Monetary Fund (1976-1982). International Financial Statistics. Washington, DC: International Monetary Fund. (Different Issues).

Isard, P. (1978). Exchange Rate Determination A Survey of Popular Views and Recent Models. Princeton Studies in International Finance, No. 42. Princeton, NJ: Princeton University Press.

Kemp, D. S. (1975). A Monetary View of the Balance of Payments. St. Louis Federal Reserve Bank Review, (April), 14-22.

Keynes, J. M. (1923). A Tract on Monetary Reform. London: Macmillan.

Laffer, A. B., \& Miles, M. A. (1982). International Economics in an Integrated World. Glenview, Il.: Scott, Foresman.

Leamer, E., \& Stern, R. M. (1970). Quantitative International Economics. Chicago: Aldine PUblishing Co.

Magee, S. (1976). The Empirical Evidence on the Monetary Approach to the Balance of Payments and Exchange Rates. American Economic Review, Papers and Proceedings, 66(2), 163-70.

Malindretos, J. (1984). The Traditional and Monetary Approaches to the Balance of Payments: A Theoretical Comparison. American Business Review, 2(1), 31-47.

Malindretos, J. (1988). The Keynesian and the Monetary Approaches to International Finance: A Reexamination. The International Journal of Finance, 1(1), 46-89.

Malindretos, J. (1991). An Examination of the Two Views of International Finance for an Advanced, Medium-Sized Reserve currency Country. Advances in Quantitative Analysis of Finance and Accounting, l(B), 183-214.

Meade, J. E. (1951). The Theorv of International Economic Policy. Volume 1: The Balance of Payments. London: Oxford University Press.

Mussa, M. (1976). The Exchange Rate, the Balance of Payments and Monetary and Fiscal Policy Under a Regime of controlled Floating. Scandinavian Journal of Economics, 78(2), 229-35. https://doi.org/10.2307/3439926

Pindyck, R. S., \& Rubinfeld, D. L. (1981). Econometric Models and Economic Forecasts. New York: McGraw-Hill.

Putnam, B. H., \& Wilford, D. S. (Eds.) (1978). The Monetary Approach to International Adiustment. New York: Praeger.

Robinson, J. (1947). The Foreign Exchanges. In J. Robinson (Ed.), Essay in the Theory of Employment (Vol. iv, 2nd ed.). Oxford: Blackwell.

\section{Copyrights}

Copyright for this article is retained by the author(s), with first publication rights granted to the journal.

This is an open-access article distributed under the terms and conditions of the Creative Commons Attribution license (http://creativecommons.org/licenses/by/4.0/). 